\title{
Sosyal Belediyecilik Uygulamalarında Kent Bilgi Sistemlerinin Kullanımı: Konya Büyükşehir Belediyesi Örneği
}

\author{
Yrd. Doç. Dr. İsmail SEVİNÇ \\ Selçuk Üniversitesi, Sağlık Bilimleri Fakültesi, Sağlık Yönetimi Bölümü, KONYA
}

\begin{abstract}
ÖZET
Sanayi Devrimi sonrası önem kazanan sosyal politikalar, ekonomik anlayışa bağlı olarak büyük değişimler yaşamıştır. 1970'li yıllardaki dünya petrol krizi ile refah devletinin girdiği dönüşüm süreci, refah belediyeciliğini de etkilemiştir. Keynesyen ekonomi politikalarının terk edilerek serbest piyasa ekonomisine doğru geçiş olarak özetlenebilecek olan bu dönüşüm sürecinde devletler asli görevlerinin dişındaki görevlerini yerel yönetimlere, özel sektöre ya da sivil toplum kuruluşlarına desantralize etmeye başlamışlardır. Merkezi yönetimlerin sosyal politika uygulamalart ile birlikte yerel yönetim birimleri de günün şartlarına uyum sağlayarak temel sosyal politika aktörleri olarak öne çıkmışlardır. Yerel yönetimlerin sosyal politika sistemi içerisindeki ă̆ırlıkları ülkeden ülkeye değişebilmekte, Türkiye'de ise son ylllarda belediyelerin sosyal politika uygulamalarıyla ön plana çıktıkları gözlemlenmektedir. Sosyal politika kavramı, yerel yönetimlerde sosyal belediyecilik adını almış; bu bağlamda Konya Büyükşehir Belediyesi'nin sosyal veri merkezi projesiyle kentin sosyal dokusuna dair detayl bir incelemesi yapılmakta, proje ile yapılan herhangi bir yardımdan diğer yardım kuruluşunun bilgisinin olması, gerçek ihtiyaç sahibine yardım yapılması, tekrarl yardımların ve istismarın engellenmesi, yardımların adaletli olarak dağıtılmast, yardım yapacak kurumun maksimum oranda bilgilendirilerek kaynak israfinın engellenmesi ve gerçek ihtiyaç sahiplerinin yardım almasının sağlanması hedef alınmıştır. Çalışmada kentsel faaliyetlerin yerine getirilmesinde optimum karar verebilmek için ihtiyaç duyulan sosyal dokuya ait verilerin önemi vurgulanmış ve elde edilen bilgiler incelenmiştir.
\end{abstract}

Anahtar Kelimeler: sosyal belediyecilik, kent bilgi sistemi, Konya Büyükşehir Belediyesi

JEL Sınıflaması: $H 7, R 5$

\section{The Use of City Information Systems In Social Municipality Services: The Case of Konya Metropolitan Municipality}

\section{ABSTRACT}

Social policies, which have gained importance after Industrial Revolution have substantially changed in line with economic understanding. With global oil crisis in the 1970s, the process of transformation in which wealth state enter has also influenced wealth. This process of transformation which can be summarized as passage to free market economy by abandoning Keynesian economic policies, governments come to decentralize their non-fundamental duties to local administrations, private sector or non-governmental organizations. Together with social policy practices of central administrations, local administrations have come to the fore as fundamental social politic actors by moving with the times. The weight of local administrations in social policy systems can vary along countries and in recent years it is seen that municipalities in Turkey has started come to the fore with social policy practices. The concept of social policy is adopted in municipal work as social municipal work. In this context, with social data center project by the Konya Metropolitan Municipality a detailed investigation is carried out on the social fabric of the city. The project aims to inform every relief institution about any relief received in the system, to help those who are indeed need, to prevent repetitive aids and thus abuse, fairly distribute relief supplies, prevent waste of recourses by informing relief institutions to a maximum extend. In this 
study, the importance of data about social fabric needed to make optimal decisions in conduction of civic services and information obtained was analyzed. municipality

Key Words: social municipal work, city information system, Konya metropolitan

JEL Classification: $H 7, R 5$

\section{GIRIŞ}

Türkiye'nin kamu yönetimi yapısı, merkezden yönetim ve yerinden yönetim sistemine dayanmaktadır. Kamu hizmetlerinin yerine getirilmesinde yetki paylaşımı, merkezi yönetimin yerel yönetimlere hizmetlerin görülmesinde yetkilerinin bir kısmını aktarması ile olmaktadır. Yerel yönetimlere dayanak teşkil eden anayasa maddesi Türkiye Cumhuriyeti'nin 1982 Anayasası'nın 123. maddesinde belirtilmiştir. Bu maddeye göre "idare kuruluş ve görevleriyle bir bütündür ve kanunla düzenlenir". İdarenin kuruluş ve görevleri merkezden ve yerinden yönetim esaslarına dayanmaktadır. Yerel yönetimler, yerel toplulukların gereksinimlerini, sorunlarını ve yerinde tespit etmek ve hizmetleri planlayarak uygulamak için örgütlenmiş kurumlardır. Gerek İl Özel İdaresi Kanunu gerekse Belediye Kanunu birbirlerine paralel olarak İl Özel İdaresi ve belediye tanımlarında aynı ifadelerle, o ilde yaşayan halkın ve belde sakinlerinin "mahalli müşterek nitelikteki ihtiyaçlarını karşılamak üzere kurulan karar organı seçmenler tarafından seçilerek oluşturulan, idarî ve malî özerkliğe sahip kamu tüzel kişisi”" olarak tanımlamaktadır. Toprak (2006:13), yerel yönetimleri merkezi yönetimin yanında ve onun yan hizmetlerini yürüten yerel nitelikte hizmet üniteleri olarak tanımlamıştır. Diğer bir anlatımla yerel yönetimler, il, belediye ve köy halkının yerel/ortak ihtiyaçlarını karşılayan ve karar organları halk tarafından seçilen kamu tüzel kişileridir. Diğer bir tanımda ise yerel yönetimler yerel bir topluluktaki bireylerin ortak gereksinimlerini karşılayan, kamu mal ve hizmetlerini sağlayan, yerel halkın kendi seçtiği organlarca yönetilen kurumlardır (Tekeli, 1992: 3).

Tarihsel süreç incelendiğinde İl Özel İdaresi, 1864 tarihli Vilayet Nizamnamesi ile il genel yönetiminin yanında valinin başkanlık ettiği ve her sancaktan seçilen dörder üyeden oluşan İl genel meclisinin bulunduğu bir özel yönetimin kurulması ile oluşmuştur. 1870 yılında çıkarılan Genel İdare Vilayet Nizamnamesi aynı sistemi korumuştur. İl genel meclisinin görev alanı biraz genişletilmiştir. 1913 yılında kabul edilen İdare-i Umumiye-i Vilayet Geçici Kanunu ile il genel yönetimi ve il özel yönetimi birlikte düzenlenmiştir. Söz konusu Kanun, il özel idarelerini düzenleyen temel metin olarak İmparatorluktan Cumhuriyet'e geçmiştir. Bu kanun çeşitli değişiklikler geçirmiş olup en kapsamlı değişikliklerden birisi de 1987 yılında yapılmış ve 1913 tarihli bu kanunun adı 3360 sayılı İl Özel İdaresi Kanunu olarak değiştirilmiştir. Son olarak 2005 y1lında 5302 say1lı İl Özel İdaresi Kanunu yürürlüğe girmiştir (2011 Y1lı Mahalli İdareler Genel Faaliyet Raporu, 2012: 4).

Türkiye'de ilk belediyecilik uygulamalarının 1854 y1lında İstanbul Şehremaneti'nin kurulmasıyla ortaya çıktığı bilinmektedir. Ancak Osmanlı Devleti'nden alınan yerel yönetim birimleri ihtiyaca cevap veremediğinden Cumhuriyet döneminde 1930 tarihli ve 1580 sayılı Belediye Kanunu çıkarılmıştır 
(Göymen, 1997:19). Zaman ilerledikçe bu kanun da ihtiyaçlara cevap verememiş, 2005 yılında 5393 sayılı Belediye Kanunu yürürlüğe girmiştir.

\section{Sosyal Devlet ve Sosyal Belediyecilik Kavramı}

Sosyal politika, ilk olarak sanayi devrimi sonucunda işçi sınıfının sorunlarıyla birlikte sanayileşmiş ülkelerde ortaya çıkmış bir kavramdır. Almanya'da Profesör Riehl tarafindan ortaya konan sosyal politika kavramı, işçileri yoksulluğa ve elverişsiz çalışma ve yaşam koşulları gibi sanayileşme ile değişen düzenin tehditlerine karşı korumayı amaç edinmiştir (Koray vd., 1995: 3). Sosyal politika, toplumda var olan sınıfsal ilişkiler, devinimler, savaşımlar ve çelişkiler karşısında devleti ve hukuksal düzeni ayakta tutmaya ve korumaya dönük çalışmaları içeren bir uğraş dalıdır (Talas, 1992:15). Şenkal (2011: 26) ise sosyal politikayı dar anlamda çıkarları uyuşmayan sınıflar arasındaki mücadeleye yönelik önlemler almak olarak tanımlarken, geniş anlamda sosyal politikayı toplumun tüm zümreleri arasındaki mücadeleler olarak ifade etmektedir. Diğer bir tanımda da Aktan ve Özkıvrak (2008: 39-77), sosyal devleti vatandaşlarına en azından asgari bir gelir ve sosyal koruma sağlamak amacıyla çeşitli maddi yararlar ve refah hizmetleri sunmak ve tam istihdam politikaları izlemek suretiyle ekonomik hayatın işleyişine müdahale eden, ekonomik hayatı yönlendiren devlet olarak ifade etmektedirler.

Sosyal politikanın kapsam ve alanı zamanla önemli değişikliklere uğramıştır. Endüstri devriminden önce sosyal politikanın kapsam ve alanını toplumdaki yoksul ve fiziksel olarak kendi kendine bakamayan kişiler (engelliler, hastalar, kimsesiz çocuklar) ve bunların ihtiyaçlarının giderilmesine yönelik sosyal refah hizmetleri meydana getirirken, 19. yüzyılda sosyal politika, ilgisini endüstrileşme ve kentleşmenin yol açtığ tehlike ve sefalete maruz kalan işçi sınıfının korunmasına yöneltmiştir. 20. yüzyılın ilk yarısından sonra ise gelişmiş ülkelerde refah devleti anlayışının benimsenmesi ve işçi sınıfinın sorunlarının eskisine oranla azalması, sosyal politikanın kapsam ve alanının çağdaş toplumsal sorunları kapsayıcı biçimde yeniden yorumlanmasına yol açmıştır. Kadınların çalışma hayatına katılımını kolaylaştırıcı önlemler ve kadınların çalışma koşullarında insan onuruna yakışır düzenlemeler yapılması, çocuk ve yaşlıların bakımı, çevre politikaları, madde bağımlılığ sosyal politikanın ilgi alanına girdiği ifade edilmektedir (Ersöz, 2014).

Sosyal devlet, liberal devletin yirminci yüzyılın ikinci yarısında kendi içinde gerçekleştirdiği bir aşamadır. $\mathrm{Bu}$ nedenle liberal devletin temel yapısı korunmakla birlikte bu yapıda gerekli ve zorunlu değişiklikler yapılmıştır. Sosyal devlet, sosyo-ekonomik hakların tanınması, bireyin bir insan olarak insanlık onurundan doğan haklarının tanımlanmasını ve herkes tarafından kullanılabilir haklar ve özgürlüklere sahip olmasını sağlamaktadır (Göze, 1995: 97).

Türkiye'de sosyal devlet uygulamalarının tarihsel olarak derin köklere sahip olduğu bilinmektedir. Sağlam bir kurumsal yapıya sahip olan vakıf kurumu ve kültürü toplumumuzda bugün bile varlığını sürdürmektedir. Ancak yerel yönetimlerin merkezinde bulunduğu, sistematik olarak sosyal politika kavramının ruhuna uygun çalışmalar henüz gelişim aşamasındadır. Sosyal belediyecilik, 
sosyal politikaların yerel yönetimler tarafından yürütülen, toplumun özellikle belediye sınırları içerisinde yaşayan halkı ilgilendiren kamu hizmetlerini kapsamaktadır. Sosyal belediyecilik ya da bir başka ifade ile belediyelerin sosyal politika uygulamaları, merkezi devletin planlamaları ve faaliyetinden farklılıklar göstermektedir. Bu farklılıklar, sosyal politikanın dar tanımı ile emek ve sermaye ilişkilerinin düzenlenmesi görevinin yerel yönetimlerin görevlerinden olmamasından kaynaklanmaktadır. Belediyeler sosyal politikalarını oluştururken, uygulamalarını genellikle sosyal politikanın araçlarından biri olan sosyal hizmet uygulamalarına yoğunlaştırırlar.

Türkiye'de devleti belli alanlara hapseden neo-liberal küreselleşme, bireylerin sosyal güvencelerinin azalmasını ve yoksulluğu da beraberinde getirmektedir. Bu durum da sosyal devlete olan ihtiyacın geçmiş yıllara oranla çok daha derinden hissedilmesine neden olmaktadır. Bir taraftan eski sosyal güvencelerin zayıflaması, diğer taraftan merkezi yönetimin küresel dönüşüme köklü çözümler üretememesi ve bireylerin sosyal politika uygulamaları bağlamında kendilerini yeterince güçlü hissetmemeleri, Türkiye'de son on yılda ikili bir yapının oluşmasına neden olmaktadır. Devlet bir taraftan yeni sosyal güvenlik yasalarıyla daha kapsayıcı politikalar üretmeye çalışırken, diğer taraftan da yapması gereken temel sosyal politika uygulamalarından özelleştirme uygulamalarıyla vazgeçmektedir. Devletin boş bıraktığı alanlar yerel yönetimler tarafından kısıtlı kaynaklarla doldurulmaya çalışılmakta ancak bu süreçte daha çok yoksul ve işsizler vb. uç grupları hedef alan politikalar üretilip toplumun omurgası ve sosyal politikaların en güçlü destekçisi olan orta gelirli kesim gözardı edilebilmektedir (Aslan, 2006:272).

Akdoğan (2006: 44) sosyal belediyeciliği, yerel yönetimlere sosyal alanlarda planlama ve düzenleme işlevi yükleyen, bu çerçevede kamu harcamalarını konut, sağlık, eğitim ve çevrenin korunması alanlarını kapsayacak şekilde sosyal amaca yönlendiren; işsiz ve kimsesizlere yardım yapılması, sosyal yardımlaşma ve dayanışmanın tesis edilmesi ile sosyo-kültürel faaliyet ve çalışmaların gerçekleştirilebilmesi için gerekli olan altyapı yatırımlarının yapılması için bilinçli politikalar üretmesini öngören; bireyler ve toplumsal kesimler arasında zayıflayan sosyal güvenlik ve adalet kavramlarını güçlendirmeye yönelik olarak yerel yönetimlere sosyalleştirme ve sosyal kontrol işlevleri yükleyen bir model olarak tanımlamaktadır.

\section{Sosyal Politika ve ile Sosyal Belediyeciliğin İlişkilendirilmesi}

II. Dünya Savaşı sonrasında ortaya çıkan yoksulluk ve eşitsizliklerle mücadelede sosyal devlet önemli fonksiyonlar üstlenmiş, ancak 1970'li y1llardan sonra sosyal politikaların devlete olan mali yükleri devleti krize sokmuş, devletler sosyal devlet olmanın gereksinimlerini karşılayamaz duruma gelmişlerdir. Merkezi yönetimlerin yerel yönetimlere devrettikleri görev alanlarından biri de sosyal yardım ve hizmetler alanı olmuştur. Dünyada 1970'li yıllarda yaşanan petrol krizi, devletlerin ekonomilerini sarsmış ve sosyal harcamalarda kısıntıya gitmelerine neden olmuştur. Bu bağlamda demografik yapıda oluşan değişimlerle birlikte ortalama insan ömrünün uzaması, yaşlı nüfusun çoğalması ve doğum 
oranlarının düşmesi aktif-pasif dengesini bozmuş, bağımlılık oranını artırmıştır. Ayrıca ekonomik büyüme hızları düşmüş, işsizlik oranları yükselmiş, kamu harcamaları artmış, vergiler yükselmiş, mali açıklar sürekli hale gelmiş, artan enflasyon oranları ile birlikte hükümetlerin sosyal harcamalar için milli gelirden ayırdıkları pay sürekli büyümüş ve giderek katlanılamaz bir hacme ulaşarak ülkelerin rekabet güçlerini zayıflatır duruma geldiği ifade edilmektedir (Özdemir, 2006: 30).

Sosyal belediyecilik, sosyal devletin yereldeki temsilcisi ya da yereldeki ortağı olan bir anlayışı kapsamaktadır. Bu bağlamda sosyal belediyecilik, belediyelere salt klasik bölgesel fonksiyonları yüklemenin ötesinde, o bölgede yaşayan bireylerin sosyal sorunlarının çözümünden de belediyeleri sorumlu tutmaktadır. Sosyal devletin yetersiz kaldığı durumlarda, sosyal belediyecilik anlayışı devreye girerek, sosyal sorunların azaltılmasında ve çözüme kavuşturulmasında önemli bir rol üstlendiği ifade edilmektedir (Selek ve Yildırımalp, 2009: 457).

Sosyal politikaların yerel düzeyde uygulayıcısı olarak yerel yönetimler, sosyal belediyecilik anlayışının gereklerini yerine getirebilmek için kentlerin fiziksel mekâna dair düzenlenmelerinden, çeşitli nüfus gruplarının öznel ihtiyaçlarını karşılamaya kadar geniş bir yelpazede işlevsel olmak zorundadırlar. $\mathrm{Bu}$ zorunluluğun arka planında, 2000'li yılların başında yeniden yapılandırılan mevzuat içinde devletin yerine getirmekle yükümlü kıldığı hizmetler ve değişen toplumsal koşulların kendi doğası gereği ortaya çıkardığı sorunlara dair bireylerin ve grupların beklenti ve taleplerinin karşılanmanın gerektiği ifade edilmektedir (Keleş, 2008:1). Sosyal belediyecilik kapsamında yürütülmesi öngörülen hizmetler aşağıdaki gibi sıralanabilir (Akdoğan, 2006: 45; Es, 2007: 30-31):

- Kimsesizlerin, evsizlerin, sokak çocuklarının ve muhtaç kadınların barınma ihtiyaçlarını karşılamak,

- Öksüzlere çocuk yuvaları ve kreşler yapmak,

- Yaşlilara huzur evleri tesis etmek,

- Sağlık merkezleri, sağlık ocakları, gezici sağlık otobüsleri, ön tanı merkezleri hizmete sokmak,

- Hastaneler civarında hasta yakınları için misafirhaneler oluşturmak,

- Kültür, sanat ve spor tesisleri açmak,

- Tiyatro, sinema, kütüphane ve kültür merkezlerini mahallelere kadar yaygınlaştırmak,

- Fakir, muhtaç ve yaşam mücadelesi veren kesimlere yönelik aş evleri ve imarethaneler kurmak,

- Engelliler için ulaşım, eğitim ve sosyo-kültürel ortamlarda kolaylık sağlayıcı önlemler almak,

- Meslek ve beceri edindirme kursları açmak,

- Park-bahçeler ve piknik alanlarını yaygınlaştırmak,

- Doğal dengeyi koruyan ve çevresel şartları düzenlenmiş ucuz konut alanları üretmek, 
- İş kuracak kadın ve gençlere yönelik rehberlik yapmak, makine ve ekipman desteği sağlamak,

- Tanzim satış mağazaları ve ekmek fabrikaları kurmak,

- Gıda, kömür, ilaç, kırtasiye malzemesi yardımı yapmak,

- Toplumsal gruplar, sivil toplum kuruluşları ve kitle örgütlerine rehberlik etmek, onlarla dayanışma ve yardımlaşmayı geliştirmek,

- Gençlerin, engellilerin ve kadınların toplumsallaşmalarını sağlayacak merkezler açmak olarak ifade edilmektedir.

III. Türkiye'de Sosyal Devletin Dönüşümü ve Yeni Kamu Yönetimi Anlayışıı

1970'li y1llarda dünyada yaşanan ekonomik kriz, hükümetlerin sosyal ve ekonomik yaşamdaki farklı ideolojik algılanışı, Keynesyen ekonomi yönetimi ve evrensel refah devleti düşüncesi üzerindeki savaş sonrası konsensusa dayalı görüşlerin erozyona uğraması, refah devletinden sosyal hizmetlere yönelik isteklerin artması ve bunun sonucunda devletlerde bütçe açıklarının görülmeye başlanması, ekonomiyi geliştirmek için en uygun kurum ve tekniklerin araştırılması, hantal, bürokratik, zorlayıcı idari yapılar içinde etkinlik ve verimliliğin artırılması çabaları, merkeziyetçi ve otoriter olarak nitelendirilen siyasal sistemlerin bile bu eğilim çerçevesinde yapılarını ve fonksiyonlarını desantralizasyon ${ }^{\bullet}$ düşüncesine göre yeniden düzenlemeye başlamaları, bu dönemde üzerinde yoğun olarak tartışılan konuların başında geldiği ifade edilmektedir (Özer, 2005: 3; Eryılmaz, 2013: 122).

Toplumsal alanda yaşanan kültürel, siyasal ve ekonomik koşullardaki değişim, dönüşüm ve gelişmeler özellikle 20. yüzyılın sonlarına doğru kamu yönetimi alanında da etkisini göstermeye başlamış; ekonomik büyümenin yavaşlaması, Sovyet Rusya'nın çöküşü ile birlikte Keynes'in sosyal refah devleti anlayışının sarsılması (Güleç, 2008: 50), küreselleşmenin etkisi ile kamu yönetimi alanında yeni talep ve ihtiyaçların ortaya çıkması ve küresel baskıların politik, ekonomik ve sosyal sistem üzerindeki etkisi ile bürokrasinin yeniden sorgulanması sonucunda devletin rolü ve büyüklüğü ile ilgili tartışmalar çoğalmıştır. Özellikle yönetim biliminde yaşanan gelişmelerin oluşturduğu klasik bürokratik örgütlenme modelinden esnek, katılımc1, yetkilendiren, etkinlik ve etkiliğe vurgu yapan, kalite odaklı ve vatandaşı müşteri olarak gören, yüksek performans hedeflerine sahip yeni bir kamu yönetimi anlayışı ortaya çıkmaya başlamıştır. Bu gelişme özellikle 1990'lardan sonra kamu yönetimi alanında yeni uygulamaların ve kavramların ortaya çıkmasına öncülük ederek kamu

- Desantralizasyon, orjin itibariyle Batı düşünce sisteminde ortaya çıkmıştır. Klasik anlamda desantralizasyon, merkezi yönetimden yerel yönetimlere doğru yetki, görev ve kaynak aktarımını ifade etmektedir. Modern anlamda desantralizasyon ise merkezi idarenin elindeki planlama, karar verme, uygulama ve kamu gelirlerinin toplanması vb. idari yetkilerin bir kısmını, taşra kuruluşlarına, yerel yönetimlere, federe birimlere, yarı özerk kamu kurumlarına, meslek kuruluşlarına ve idarenin dışındaki gönüllü örgütlere aktarılmasıdır. Kısaca desantralizasyon,, merkezi idarenin küçültülmesi olarak ifade edilmektedir (Eryılmaz, 2013: 123). 
yönetiminde bir değerler dizisi değişiminin yaşanmasını zorunlu kıldığ1 ifade edilmektedir (Kurt ve Uğurlu, 2007: 81-82; Ökmen ve Parlak, 2008: 344). 1980’li yılların başından itibaren geleneksel devlet anlayışının yerini yeni devlet anlayışına bıraktığı görülmekte; bu bağlamda söz konusu süreçte geleneksel devlet anlayışına egemen olan değer ve ilkelerde eleştirilmeye ve sorgulanmaya başlamıştır. Geleneksel kamu yönetimi anlayışında yaşanan değişim sonucunda özel sektörde uygulanan yönetim tekniklerinin kamu sektörüne adapte edileceği, katı kurallara bağlı olmayan esnek yönetim anlayışının benimseneceği, kamu yönetiminin rasyonel esaslara göre işleyen bir yapıya kavuşturulacağı ve daha katılımcı bir yönetim yaklaşımının yerleştirileceği öngörülmektedir. Bu noktada geleneksel kamu yönetimi anlayışının terk edildiği, yeni kamu yönetimi anlayışına geçildiği ve yönetim anlayışında bir paradigma değişiminin yaşandığı ifade edilmektedir

\section{Türkiye'de Sosyal Belediyeciliğin Hukuksal Çerçevesi}

1982 Anayasası başlangıç bölümünde, her Türk vatandaşının bu anayasadaki temel hak ve hürriyetlerden eşitlik ve sosyal adalet gereklerince yararlanarak milli kültür, medeniyet ve hukuk düzeni içinde onurlu bir hayat sürdürme, maddi ve manevi varlığını bu yönde geliştirme hak ve yetkisine doğuştan sahip olduğu belirtilmektedir. Yine anayasanın başlangıç bölümünde devletin temel amaç ve görevleri, Türk milletinin bağımsızlığını ve bütünlüğünü, ülkenin bölünmezliğini, cumhuriyeti ve demokrasiyi korumak, kişilerin ve toplumun refah, huzur ve mutluluğunu sağlamak; kişilerin temel hak ve hürriyetlerini, sosyal hukuk devleti ve adalet ilkeleriyle bağdaşmayacak surette sinırlayan siyasal, ekonomik ve sosyal engelleri kaldırmaya, insanın maddi ve manevi varlığının gelişmesi için gerekli şartları hazırlamaya çalışmak olarak belirtilmektedir (www.mevzuat.gov.tr, 2014).

Türkiye'de yerel yönetimler, 1982 Anayasası'nın 123. ve 127. maddelerinde düzenlenmiştir. 123. maddede idarenin bütünlüğü ilkesi vurgulanmakta, idarenin hem merkezden yönetim hem de yerinden yönetim esaslarına dayandığı ifade edilmekte; 127. maddede ise yerel yönetimlerin kuruluş esasları, seçimler, idari vesayetin hangi durumlarda kullanılacağ Ayrıca yerel yönetimlerin kademeleri, seçim usulleri, İçişleri Bakanlığg tarafından denetimi, idarenin bütünlüğü ilkesine uygun hareket etmesi ve sorumluluklariyla doğru orantılı gelir sağlanması ilkeleri açıklanmaktadır (Toksöz vd., 2009: 49). Gerek Belediye Kanunu ve diğer yerel yönetim birimlerin teşkilat kanunları, gerekse kadük olan Kamu Yönetimi Temel Kanun Tasarısı, 1980'lerden beri kamu yönetiminde gündemde olan yönetimde reform talep ve ihtiyaçlarının bir sonucu olarak ortaya çıkmıştır. Avrupa Birliği üyelik sürecinde uyulması gereken müktesebat düzenlemeleri de bu süreci hızlandıran bir faktör olarak ortaya çıkmaktadır. Yönetimde şeffaflık, halkın katılımı, hesap verilebilirlik, yerindelik vb. iyi yönetişim ilkeleri her alanda olduğu gibi yerel yönetim kanunlarının da altyapılarının temelini oluşturduğu ifade edilmektedir (Özden ve Zorlu, 2010: 39). Bu bağlamda Türkiye' deki sosyal belediyeciliğin hukuksal çerçevesini çizebilmek için 5393 Sayılı Belediye Kanunu, 5216 Sayılı Büyükşehir Belediyesi Kanunu ve 
5302 Sayılı İl Özel İdaresi Kanunu'nu incelemek gerekmektedir (Pektaş, 2010: $12)$.

\section{A. 5393 Sayılı Belediye Kanunu'nda Sosyal Belediyecilik}

5393 sayılı Belediye Kanunu'na göre belediye, belde sakinlerinin yerel ortak nitelikteki ihtiyaçlarını karşılamak üzere kurulan ve karar organı seçmenler tarafından seçilerek oluşturulan, idarî ve malî özerkliğe sahip kamu tüzel kişisi olarak ifade edilmektedir (www.mevzuat.gov.tr, 2014). 5393 say1lı Belediye Kanunu ile belediyelere sosyal politika ve sosyal hizmetlerle ilgili görevlerin verildiği görülmektedir. $\mathrm{Bu}$ görevler aşağıdaki gibi sıralanabilir (www.mevzuat.gov.tr, 2014):

- Herkes ikamet ettiği beldenin hemşehrisidir. Hemşehrilerin, belediye idaresinin yardımlarından yararlanma hakları bulunmaktadır. Yardımların insan onurunu zedelemeyecek koşullarda sunulması zorunludur (md. 13/1).

- Belediye, hemşehriler arasında sosyal ve kültürel ilişkilerin geliştirilmesi ve kültürel değerlerin korunması konusunda gerekli çalışmaları yapar. $\mathrm{Bu}$ çalışmalarda üniversitelerin, kamu kurumu niteliğindeki meslek kuruluşlarının, sendikaların, sivil toplum kuruluşları ve uzman kişilerin katılımını sağlayacak önlemler alınır (md. 13/3).

- Belediyeler (mahalli müşterek nitelikte olmak şartıyla), sosyal hizmet ve yardım, nikâh, meslek ve beceri kazandırma; ekonomi ve ticaretin geliştirilmesi hizmetlerini yapar veya yaptırmakla görevlendirilmiştir (md. 14/a).

- Büyükşehir belediyeleri ile nüfusu 50.000’i geçen belediyeler, kadınlar ve çocuklar için koruma evleri açarlar (md. 14/a).

- Belediyeler (mahalli müşterek nitelikte olmak şartıyla), sağlıkla ilgili her türlü tesisi açabilir ve işletebilirler (md. 14/ b).

- Belediyeler (mahalli müşterek nitelikte olmak şartıyla), gıda bankacılığ yapabilirler (md. 14/b).

- Belediyeler hizmet sunumunda engelli, yaşlı, düşkün ve dar gelirlilerin durumuna uygun yöntemler uygulamak durumundadırlar (md. 14/b).

- İl sınırları içinde büyükşehir belediyeleri, belediye ve mücavir alan sınırları içinde il belediyeleri ile nüfusu 10.000 'i geçen belediyeler, meclis kararıla; sağlı, eğitim, sosyal hizmeti geliştirecek projelere İçişleri Bakanlığı'nın onayı ile ücretsiz ya da düşük bir bedelle amacı dışında kullanılmamak kaydıyla arsa tahsis edebilirler (md. 15).

- Belediyeler, dar gelirli, yoksul, muhtaç ve kimsesizler ile engellilere yapılacak sosyal hizmet ve yardımlar konusunda bütçeye ödenek koyabilir ve harcama yapabilirler (md. 60/i).

- Belediyeler, dar gelirli kişiler ile afete maruz kalanlara arsa tahsisi yapabilirler (md. 69/3).

- Belediyeler sağlık, eğitim, çevre, sosyal hizmet ve sosyal yardım hizmetleriyle yaşlılara, kadın ve çocuklara, engellilere, yoksul ve düşkünlere yönelik hizmetlerin yapılmasında beldede dayanışma ve katılımı sağlamak, hizmetlerde etkinlik, tasarruf ve verimliliği artırmak amacıyla gönüllü kişilerin katılımına yönelik programlar uygulamakla görevlidirler (md. 77/1). 


\section{B. 5216 Sayılı Büyükşsehir Belediyesi Kanunu'nda Sosyal Belediyecilik}

5216 Say1lı Kanun'a göre büyükşehir belediyelerine yüklenen sosyal belediyecilik bağlamında görevler aşağıdaki gibi sıralanabilir (www.mevzuat.gov.tr, 2014):

- Büyükşehrin bütünlügü̈ne hizmet eden sosyal donatılar, bölge parkları, hayvanat bahçeleri, hayvan barınakları, kütüphane, müze, spor, dinlence, eğlence ve benzeri yerleri yapmak, yaptırmak, işletmek ya da işlettirmek; gerektiğinde amatör spor kulüplerine malzeme vermek ve gerekli desteği sağlamak, amatör takımlar arasında spor müsabakaları düzenlemek, yurt içi ve yurt dış1 müsabakalarda üstün başarı gösteren veya dereceye giren sporculara belediye meclis kararıyla ödül vermek (md. $7 / \mathrm{m}$ ).

- Gerektiğinde sağlık, eğitim ve kültür hizmetleri için bina ve tesisler yapmak, kamu ve kuruluşlarına ait bu hizmetlerle ilgili bina ve tesislerin her türlü bakımını, onarımını yapmak ve gerekli malzeme desteğini sağlamak (md.7/n).

- Sağlık merkezleri, hastaneler, gezici sağllk üniteleri ile yetişkinler, yaşl1lar, engelliler, kadınlar, gençler ve çocuklara yönelik her türlü sosyal ve kültürel hizmetleri yürütmek, geliştirmek ve bu amaçla sosyal tesisler kurmak, meslek ve beceri kazandırma kursları açmak, işletmek ya da işlettirmek, bu hizmetleri yürütürken üniversiteler, yüksekokullar, meslek liseleri, kamu kuruluşları ve sivil toplum örgütleri ile işbirliği yapmak (md.7/v).

Yürürlükten kalkan 1580 sayılı Belediye Kanunu'na göre belediyelerin sosyal belediyecilik yapabilmelerine olanak sağlayacak düzenlemeler bulunmadığından, yürürlükten kalkan kanunlarla belediyelerin bu tür faaliyetlerinin yetersiz olduğu düşünülmektedir. Yeni yasalarla birlikte belediyelere sosyal belediyecilik faaliyetleri, görev ve sorumluluk olarak yüklenmiştir. Eski kanunlarla belediyelere kentin altyap1 ve üstyapısı ile ilgili düzenlemeler yapma yetkisi verilmişken yeni kanunlarla belediyelere sosyal alanda belediyecilik yapma yolu açılmıştır. Bu bağlamda belediyelerin yeni yasalarla sosyal belediyecilik uygulamalarına çok daha fazla yer verdikleri görülmektedir.

\section{5302 Sayılı İl Özel İdaresi Kanunu'nda Sosyal Belediyecilik}

04.03.2005 tarihli ve 5302 sayılı İl Özel İdaresi Kanunu'na göre il özel idaresi, il halkının yerel ortak nitelikteki ihtiyaçlarını karşılamak üzere kurulan ve karar organı seçmenler tarafindan seçilerek oluşturulan, idarî ve malî özerkliğe sahip kamu tüzel kişisi olarak tanımlanmıştır (md. 3/a). İl özel idarelerinin görevleri, il sınırları içindeki görevleri ve belediye sınırları dışındaki görevleri olmak üzere ikili bir ayırıma tabi tutulmaktadır. Buna göre il özel idareleri mahallî müşterek nitelikte olmak şartıyla (md. 6);

- İl sınırları içinde: sağlık, tarım, sanayi ve ticaret; ilin çevre düzeni plânı, bayındırlık ve iskân, toprağın korunması, erozyonun önlenmesi, sosyal hizmet ve yardımlar, yoksullara mikro kredi verilmesi, çocuk yuvaları ve yetiştirme yurtları; ilk ve orta öğretim kurumlarının arsa temini, binalarının yapım, bakım ve onarımı ile diğer ihtiyaçlarının karşılanmasına ilişkin hizmetler ile; 
- Belediye sınırları dışında: imar, yol, su, kanalizasyon, katı atık, çevre, acil yardım ve kurtarma, kültür, turizm, gençlik ve spor; orman köylerinin desteklenmesi, ağaçlandırma, park ve bahçe tesisine ilişkin hizmetleri yapmakla görevli ve yetkili kılınmıştır. Yine ilgili kanunda belediyelere olduğu gibi il özel idarelerine de sosyal hizmetler ve yardımlara ilişkin görevler verilmiştir. Ayrıca dar gelirli, yoksul, muhtaç ve kimsesizlere yapılacak sosyal hizmet ve yardımlar (md. 43/h) il özel idaresinin giderleri arasında sayılmış ve bütçede yoksul ve muhtaçlar için ayrılan ödeneği kullanma yetkisi de valiye verilmiştir (md. 30/n).

\section{Konya Kent Bilgi Sistemi ve Türkiye'de İlk Kez Uygulanan Sosyal Veri Merkezi}

Kent bilgi sistemi, kent yönetiminde yer alan araştırma, planlama, uygulama ve karar verme organlarının; daha hızlı ve daha doğru bir şekilde sonuca ulaşmaları ve karar vermeleri için gerekli ihtiyaçları karşılayacak ve kentin çağdaş bir yönetim şekliyle yönetilmesine olanak sağlayacak yeni bir anlayış, yeni bir yapılanma ve yeni bir uygulama şekli olarak ifade edilmektedir (İçişleri Bakanlığı, 2007: 10). Diğer bir tanımda ise kent bilgi sistemi, kentsel faaliyetlerin yerine getirilmesinde optimum karar verebilmek için ihtiyaç duyulan planlama, altyap1, mühendislik, temel hizmetler ve yönetimsel bilgileri hızlı ve sağlıklı bir şekilde irdelemek amacı ile oluşturulan coğrafi bilgi sistemlerinin kent bazındaki bir uygulamasıdır (www.konya.bel.tr, 2014). İçeriği, ne gibi unsurlar ve sorumluluklar yüklediği kamuoyu tarafindan pek de bilinmeyen ama kamuoyunun bir ideal olarak baktığı, bu konuda fikir yürütebilen ilgili kişilerin perspektifine göre birçok meselede kurtarıcı gözüyle bakılan kent bilgi sistemlerinin uygulandığında kentsel bazda birçok sorunun çözüleceği düşünülmektedir. Ancak Türkiye'deki yanlış örnekler ya da istismarlar nedeniyle sisteme temkinli yaklaşılmaktadır. Özellikle belediyeler halka hesap veren kurumlar olduğu için kent sakinleri tarafından görülmeyen böyle bir çalışmanın sorumluluğunu almak belediyeler tarafindan bir risk olarak görülmektedir.

2004 yılı içinde başkanlık makamının girişimi ile Konya ili genelindeki tüm kurumların yer aldığı Coğrafi Bilgi Sistemi Koordinasyon Kurulu oluşturulmuş, bu koordinasyona tüm kurumlardan temsilciler istenmiş, süreç içerisinde Konya'ya ait güncel bir haritanın olmamasının ciddi bir sorun olduğu, sistemin sadece harita unsurundan oluşmadığı, yazılım ve bilgi işlem unsurlarının var olduğu, planlı bir şekilde bilgi sistemi oluşumuna başlanması gerektiği ifade edilmiş; sistemi kurup ölü doğmasını engelleme, güncelleme sorunları vb. sorunlar tüm kurumların ortak endişesi olarak ortaya çıkmış, sistemin tüm disiplin ve meslekler ile ilişkili olduğu tartışılmıştır.

Bilgi sisteminin oluşturulmasının sadece harita ile olmayacağı gibi sadece verileri analiz eden, değerlendiren, ilişkiler kuran, yazılım kurguları yapan coğrafyanın ne demek olduğunu algılayamayan bir bilgi işlem yapısı ile de mümkün olmayacağı tartışılmış, bu nedenle birim İmar ve Şehircilik Daire

- Bilgiler, Konya Büyükşehir Belediyesi'nin web sayfasından derlenmiştir. 
Başkanlığ1 uhdesinde ve sorumluluğunda kurgulanması gerektiği bilgi işlem unsurlarının var olduğu, yazılım kodlaması bilen ekiplerin mekân bilgisini algılamayı öğrendiği, mekân bilgisi olan her türlü mühendis ya da şehir plancının da yazılım olgularını ögrenmesi gereken bir unsur olduğu, sorumlu ve muhatap bir birim kurulması gerektiği kararlaştırılmıştır. 5216 sayılı Büyükşehir Belediyesi Kanunu'nun 7/h maddesi, coğrafi bilgi sistemi ve kent bilgi sistemi kurma görevini belediyelere vermesiyle 13.06.2005 tarihinde 74 sayıl1 Büyükşehir Belediye Meclisi'nin Kent Bilgi Sistemi ile ilgili birimin oluşturulması kararı alınmıştır. Konya kent bilgi sisteminin kurulmasıyla günümüz bilgi teknolojileri ve uygulamaları destekli bir bilgi sisteminin Büyükşehir Belediyesi bünyesinde kurulup yaygınlaştırılması, bunların sağladığ1 yararların internet tabanlı sistemler aracilığıla belediyenin ve vatandaşların kullanımına sunulması, özellikle Konya'ya ait teknik, sosyal ve ekonomik durumun coğrafi bilgi sistemi teknolojisinden yararlanılarak çıkarılması, belediye çalışmalarında hizmet verimliliğinin, hızın, kalitenin yükseltilmesi, kent yöneticilerine güncel verilere dayalı karar destek sistemleri ile daha hızlı ve doğru kararlar verme olanağının sağlanması hedeflenmektedir. Kent bilgi sistemlerinin kapsama alanı aşağıdaki unsurlardan oluşmaktadır:

- Sistem analizi ve tasarımı, sistemin yaşatılmasına yönelik veri güncelleme yaklaşımları,

- Yüksek çözünürlüklü görüntünün temini,

- Numarataj bilgilerinin Türkiye İstatistik Kurumu standartlarına göre toplanması, güncellenmesi, sayısallaşması ve Kamu Hesapları Bilgi Sistemi'ne (KBS) entegrasyonu, web ortamında kent rehberi çalışması,

- Kadastro bilgilerinin tamamı ile sayısallaşması (Tapu Kadastro Genel Müdürlüğü ile yapılan yazışma ve protokoller gereğince Tapu ve Kadastro Bilgi Sistemi'nden (TAKBİS) alınması kararlaştırılmıştır),

- Tapu bilgileri ile kadastro verilerinin ilişkilendirilmesi, entegrasyonu,

- Kadastro ve tapu bilgilerinin coğrafi bilgi sistemlerine (CBS)

- İmar planlarının topolojik veri yapılarına kavuşturulması ve KBS ile entegrasyonu,

- İller Bankası'nca üretilen güncel harita verilerinin topolojik veri yapılarının kurulması ve KBS'ye entegrasyonu,

- Saha Anket Çalışması (Sosyal Doku Haritası) ve anket verilerinin KBS'ye entegrasyonu, sosyo-ekonomik analizlerin yapılması ve kartografik harita çıktılarının alınmasına yönelik ara yüzlerin hazırlanması,

- CBS fonksiyonlarını yerine getirebilen yazılım, web tabanlı CBS Server sistemi, veritabanı yazılımına bağlı gerekli diğer programların sağlanması,

- Eğitim hizmetleri,

- Sisteme teknik destek ile yazılım güncelleme hizmetleri.

5216 sayılı Büyükşehir Belediyesi Kanunu'nun $7 / \mathrm{v}, 8 / \mathrm{m}$ ve $24 / \mathrm{j}$ maddeleri, büyükşehir belediyelerine dar gelirli, yoksul, muhtaç ve kimsesizler ile engellilere sosyal hizmet ve yardım sunma görevi vermiştir (www.tbmm.gov.tr, 
2014).

Bu bağlamda Konya Büyükşehir Belediyesi bünyesinde yardımların evrak kayıt ortamı ile birlikte coğrafi bilgi sistemi ortamına taşınması, yapılacak yardımın kent bütününde dağılımını ve yardıma ihtiyacı olan/olacak bölgelerin tespit edilmesi, CBS ortamında bulunan diğer unsurlardan (Adrese Dayalı Nüfus Kayıt Sistemi, TAKBİS, ikamete ait bina fotoğrafı uydu görüntüsü vb.) maksimum oranda yararlanarak yardımların reel, adaletli ve işlevsel olması hedeflenmiştir.

Sosyal veri merkezi projesi ile Türkiye'de ilk defa sosyal doku haritası üretimi gerçekleştirilerek elde edilen veriler belediye faaliyetleri kapsamında kullanılması gerçekleştirilmiş; bu bağlamda Sosyal Bilgi Merkezi, 5216 sayılı Büyükşehir Belediyesi Kanunu'nun 7/h maddesi gereğince, Konya Büyükşehir Belediyesi bünyesinde kurulan Coğrafi Bilgi Sistemi tabanlı veritabanı üzerinde kurgulanmıştır. Proje ile yapılan herhangi bir yardımdan diğer yardım kuruluşunun bilgisinin olması, gerçek ihtiyaç sahibine yardım yapılması, tekrarlı yardımların ve istismarın engellenmesi, yardımların adaletli olarak dağıtılması, yardım yapacak kurumun maksimum oranda bilgilendirilerek kaynak israfinın engellenmesi ve gerçek ihtiyaç sahiplerinin yardım almasının sağlanması hedeflenmiştir.

Sosyal Doku Haritası ile Sosyal Bilgi Merkezi oluşumuna neden olan mevcut ve güncel yardım verileri ile haneler birebir gezilerek elde edilen anket verileri çaprazlanarak yardım yönelimlerinin değerlendirilmesi, bütünden özele inilmesi ile belli bölgelere odaklanılması, nedensellikler sorgulanarak yardımdan ziyade ilgili bölgelere KOMEK (Konya Büyükşehir Belediyesi Meslek Edindirme Kursları) vb. unsurlar ile belediye ve merkezi hükümetin sağlayabileceği istihdamın unsurlarının değerlendirilmesi, buralarda yaşayan insanlara yeni mesleki beceriler vererek bir aşamaya kadar yardım etmek, belli bir aşamadan sonra ise ilgili kişilere sağlanan istihdamlar ile ev ekonomisine katkı sağlamak, atıl kalan iş gücünün üretime katılması hedeflenmiştir. Kent bilgi sistemi çalışmaları bağlamında sosyal veri merkezinin oluşturulma nedenleri aşağıdaki gibi siralanabilir:

- Yardım dağıtımı işlemi esnasında yardım alacak kişinin durumu hakkında uzun ya da kısa süreli araştırma evresi gerçekleşmekte ve bu durum gerçek ihtiyaç sahibini gerekli ihtiyacı alamadığından ötürü daha da zor duruma düşürebilmekte,

- Belediye ve yardım dağıtmakla görevli kurum ve kuruluşların yapmış olduğu yardımlar bazı ihtiyaç sahibi görünümlü art niyetli kişilerce rant unsuru haline getirilmekte, ciddi anlamda yardımlar istismar edilebilmekte,

- Kurum ve kuruluşlar için dağıtılacak yardım; kendisine beyanda bulunan kişiler için sınırlı kalmakta, çeşitli insani nedenlerden ötürü yardım talep edemeyen gerçek ihtiyaç sahiplerinin mağdurlukları devam edebilmekte,

- Yardım çerçevesinde elde edilen kayıtlar tam bir standart içermemekte, dolayısıyla kurumlar birbirlerinin yaptığı yardımı bil(e)mediklerinden aynı kişiye tekrar yardım yapılabilmektedir. 
Şekil 1. Yardım Başvuru Döngüsü

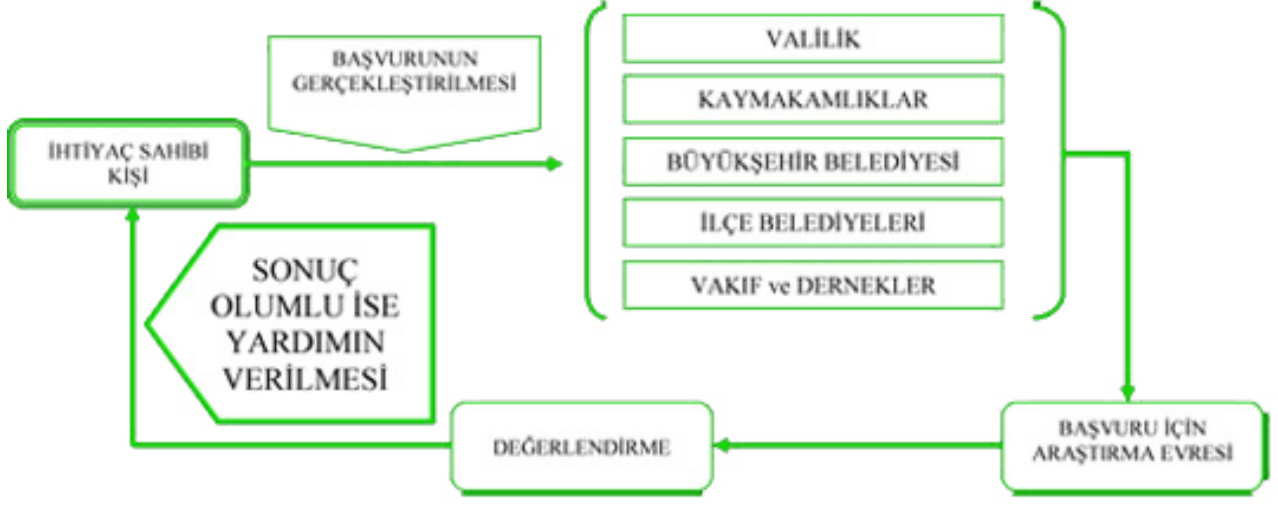

Kaynak: www.konya.bel.tr, 2014.

Yukarıda belirtilen döngü içerisinde kurumların hangi yardımları verdiğinin bilgisi kendi aralarında genellikle bilinmemesi ve gerekli denetim mekanizmalarının tam işletilmemesi sonucunda yardım hizmetinin suiistimal edilmesine yönelik unsurları beraberinde getirmektedir. Araştırma evresinin kimi kurumlar için uzun sürmesi yardımı geciktirmekte; özellikle resmi kurumlar yardım yapma öncesinde yardım yapılacak kişiyi ifşa edecek, gurur ve onurunu rencide edecek şekilde kişinin gerçekten yardıma ihtiyacı bulunduğunu belgelemek açısından muhtarlıklardan, üzerinde mal olup olmadığını tapu sicil müdürlüklerinden ve belediyelerin verdikleri "sözüm ona usul yerini bulsun" belgeleri ile yapmaktadır. Kimi organizasyonlar içinse; "nasıl olsa birileri yardım yapıyor bunun bir şekilde dağıtılması gerektiği" mantığından veya "kısa zaman aralığında dağıtılmaması" başka maddi külfetleri beraberinde getirdiğinden (depo, soğuk hava deposu vb.) yeterince inceleme yapılmaksızın yardımların yapılmasını sağlamakta, bu durum da başka sorunlara yol açabilmektedir.

Yardım, kendine mahsus basit bir kavram değildir. Yardım, sorgulanması gereken (sosyal, iktisadi vb.) birçok sorunu bünyesinde barındırmaktadır. Devletin veya yardım kuruluşlarının yardım yapması sosyal devlet olmanın bir gereğidir. Yardım yapılan mekân ve insan bilgisinin izlenilmesi ile bu unsurların CBS tabanlı bir veri tabanında sorgulanması, takip edilmesi başka unsurlar ile birlikte (istihdam, planlama vb.) analiz edilerek kullanılması da bu sosyal devlet anlayışının bir gereğidir.

Sosyal veri merkezi modelinin dayanmış olduğu temel; yardım dağıtmakla görevli organizasyonların yardım faaliyetleri açısından tek bir merkeze toplanması, aralarında bilgi paylaşımının sağlanması ve yardım için araştırma evresinin, mevcut var olan kent bilgi sistemi altyapısının da kullanılması ile kolaylaştırılmasıdır. $\mathrm{Bu}$ model kapsamında amaç, verilerin tek bir kurumun tekelinde toplanmasından ziyade tüm organizasyonların sahip olduğu yardım verilerinin bir havuz içerisinde toplanarak destekleyici teknolojiler kapsamında uygun standartlar içerisinde yardım hizmetini gerçekleştirmektir. 
2009 yılında projenin veri tabanını oluşturmak amacıyla Konya'nın merkez ilçeleri olan Meram, Karatay ve Selçuklu'da anket çalışması yapılmış, Karatay'da 36331, Meram'da 54728 ve Selçuklu ilçesinde 89930 kişiye söz konusu anket uygulanmıştır. Anket sorularında ikamet şekli (ev sahibi, kiracı, lojman), 1sınma türü (doğalgaz, elektrik, fuel oil, katı yakıt), devamlı hasta varlığı, şehir dışında öğrenci varlığı, engelli varlığı, hane geliri, internet bağlantısı, araç sahipliğii, sosyal yardıma ihtiyaç durumu, eş durumu (ölü, sağ), sosyal güvence varlığı, belediye hizmetlerinin yeterliliği, işsiz sayısı, çalışan sayısı, hane halk1 sayısı ve hanede öğrenim gören sayısı konularında veri elde edebilmek için sorular sorulmuştur.

Projede teknolojik altyapı olarak kent bilgi sistemi altyapısı kullanılmıştır. Coğrafi yapıya bağlı kent bilgi sistemi temeli, yardımı sunan merkezi ve yerel kuruluşların yardım kayıtlarını bünyelerinde teknolojiye bağımlı ya da bağımsız olarak barındırmaktadırlar. Böylesi bir durum beraberinde birçok onay sürecine dayalı resmi prosedürleri içermektedir. Halbuki kişinin adresi ve kimlik bilgileri devlet tarafından rahatlıkla bilinebilecek kavramlardır. Coğrafyadan bağımsız gerçekleştirilen bu süreçte yardım verilen kişilerin coğrafi dağılımı, analizi ve gerçek ihtiyaç sahiplerinin kendilerinden habersiz tespit edilmesi mümkün olmamaktadır.

Sosyal bilgi merkezi projesi ile "Mekansal Anahtar" diye adlandırılan ve coğrafi bilgi teknolojilerine dayalı yapılanma üzerinde gelişim sağlanmıştır. Bu bağlamda ihtiyaç sahibi olup başvuru gerçekleştiremeyen mağdur kişilere de ulaşabilme durumu olabilmektedir. "Mekansal Anahtar" kavramı aşağıdaki şekilde açıklanmaktadır:

• TÜiK verilerine göre 2009 yılı nüfus sayımında Selçuklu'nun nüfusu 487.899, Meram'ın 309.276, Karatay'ın 257.639 olarak tesbit edilmiştir. Rakamlar, Konya Büyükşehir Belediyesi İmar ve Şehircilik Dairesi Başkanlığı Kent Bilgi Sistemi Şube Müdürlüğ̈̈nden ve TÜİK'in web sayfasından temin edilmiştir. 
Şekil 2: Mekansal Anahtar Yapısı

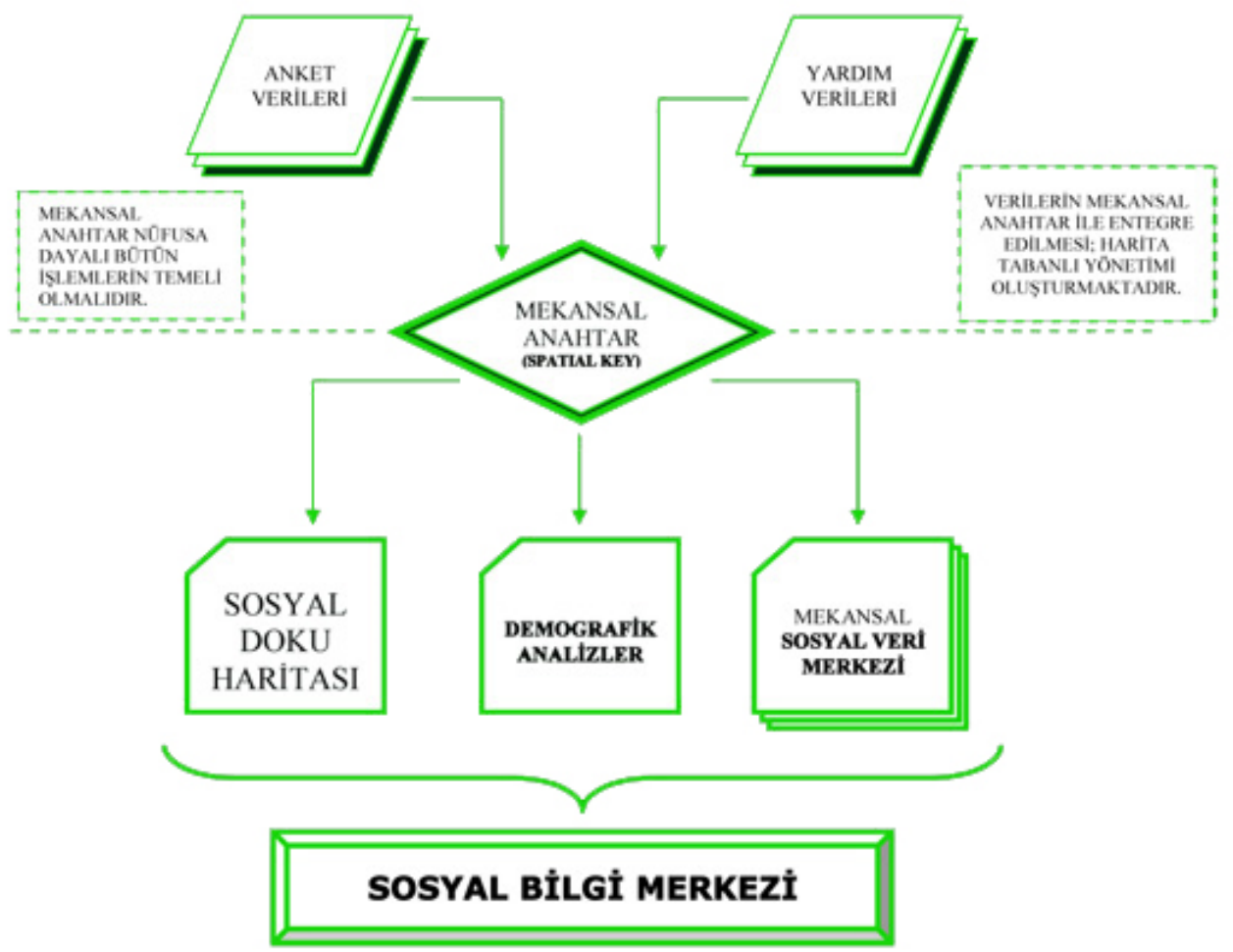

Kaynak: www.konya.bel.tr, 2014.

Mekansal anahtar; adres bilgilerini, bina bilgilerini, nüfus hizmetlerine dayalı kişi bilgilerini birbiri ile ilişkili olarak sunan bir yapılanma olarak tasarlanmıştır. Diğer bir anlatımla bu yapılanmaya kent bilgi sistemi çekirdek yapısı da denilebilir. Bu bağlamda kişiye ait sosyal veriler elde edilerek projeye entegre edilmiş ve harita tabanlı sunulan hizmetlerin gerçekleştirilmesi mümkün olmuştur. Sosyal Bilgi Merkezi projesinin sahip olduğu orta vadeli hedefler aşağıdaki gibi sıralanabilir (www.konya.bel.tr, 2014):

- Mevcut yardım verilerinin ıslahının tam olarak gerçekleştirilmesi ile proje kapsamında kullanılmasını sağlamak,

- Yardım dağıtan yerel yönetimler, vakıflar ve dernekler için yazılım altyapısının yaygın hale getirilmesi ile kayıt ortamının tek bir merkeze dayalı olarak yaşatılmasını sağlamak,

- Aylık dönemler halinde kent genelinde yapılacak analizler ile ihtiyaç sahiplerinin, kendilerinin haberi olmaksızın tespit edilmesini sağlamak ve yardım türlerini yönlendirmek.

Sosyal Bilgi Merkezi'nin sahip olduğu uzun vadeli hedefler ise;

- İhtiyaç sahipliliği kavramını planlama, istihdam, hizmet v.b. kentsel faaliyetler ile ortadan kaldırmak,

- Yardımların adil dağılımını sağlamak, 
- E-devlet olanakları ve projenin eşleştirilmesi ile ihtiyaç sahibini rencide etmeyecek araştırma metotları ile hakkında tam ve net bilgi sahibi olmayı sağlamak,

- Adrese dayalı nüfus kayıt sistemi (ADNKS) altyapısının coğrafi bilgi sistemi temeline oturtulmasına katk1 sağlayarak ülke genelinde; yardımların, nüfus hizmetlerinin ve nüfusa dayalı işlemlerin coğrafi bilgi sistemi destekli edevlet imkanları ile gerçekleştirilmesini sağlamak,

- Elektronik imza altyapısının kullanılması ile yardım hizmetlerinin sağlanması olarak sıralanmaktadır.

\section{SONUÇ}

Günümüzde belediyeler gittikçe artan oranda sosyal belediyecilik faaliyetlerini sürdürmekte; ancak belediyelerin bu yöndeki faaliyetlerinin yeterince gündeme getirilmediği görülmektedir. Küreselleşme ile birlikte sosyal yaşamdaki değişikliklere uygun olarak ortaya çıkabilecek ya da ortaya çıkan sorunlara çözüm sunacak hem resmi kurumların hem de sivil kurumların yeniden yapılandırılmaları gerekmektedir. Eskiye nazaran aile bağlarının zayıflaması, geniş aileden çekirdek aileye doğru yaşanan dönüşüm, aile içi şiddetin artması, emeğini sunarak çalışan kesimlerin sosyal haklarından mahrum kalma ihtimali vb. olumsuz durumlara karşı kurumların proaktif bir tavır sergilemeleri gerekmektedir.

Belediyelerin sosyal yardım amaçlı yapılan çalışmalarında bazı insanların bunu meslek haline getirdikleri ve başta belediyeler olmak üzere birçok kurumdan yardım aldıkları bilinmektedir. $\mathrm{Bu}$ bağlamda bu tür suistimallerin önüne geçebilmek için altyapısı çok güçlü bir bilgi sistemi kurulmalı, kişilerle ilgili tüm veriler sisteme kaydedilmelidir. Konya Büyükşehir Belediyesi’nin sosyal veri merkezi projesi ile kişilerin tüm bilgileri kayıt altına alınmakta, sosyal yardımların kötü niyetli kişilerce kullanımının önüne geçilmekte, gerçekten ihtiyaç sahibi kişilere sosyal yardımlar ulaştırılmaktadır.

Sosyal yardım ulaştırılan kişilerin zihinlerinde bu yardımların sürekli olacağ 1 yönünde bir algının oluşmaması önem arz etmektedir. Kişilerin bir mesleki beceriye sahip olmalarını sağlama, bu yönde eğitim verme, belediyelerin yine bu bağlamda görevleri arasında sayılabilir. İnsanları devamlı hazırdan yardım alma yerine bir meslek edindirerek onların da kendi ihtiyaçlarını giderebilme yönünde belediyelerin istihdam olanakları sunmalarının yerinde bir uygulama olacağı düşünülmektedir.

Bilgi çağında kamu kurumlarının vatandaşlarına web tabanlı uygulamalarını etkin bir şekilde kullanabilmeleri için gerekli altyapıyı sunması gerekmektedir. Konya Büyükşehir Belediyesi'nin web sayfası incelendiğinde sosyal yardım almak isteyen vatandaşların nasıl bir yol izleyecekleri konusunda yeterince bilgi ve belge sunulmadığ görülmektedir. Bu durum zaten ihtiyaç sahibi olan kişinin belediye binasında kapı kapı dolaşmasına neden olabilecek, insanlık onuruna dokunan bir durum olabileceği için vatandaşların sosyal yardım başvurularını internet ortamında da yapabilmelerini sağlayacak düzenlemelerin ivedilikle yapılması önerilmektedir. Kişinin başvurusu, sosyal bilgi merkezindeki 
bilgi ve belgelerle karşılaştırılarak gerçekten ihtiyaç sahibi olup olmadığına daha etkin bir şekilde karar verilebileceği düşünülmektedir.

\section{KAYNAKÇA}

AKDOĞAN, Yalçın (2006), "Sosyal Belediyecilik", İstanbul: Yerel Siyaset, Yı1: 1, S: 3.

AKTAN, Coşkun Can ve Özlem Özkıvrak (2008), Sosyal Refah Devleti, İstanbul: Okutan Yayincilik.

AYSAN, Mehmet Fatih (2006), Küreselleşme Bağlamında Türkiye'de Sosyal Politikaların Dönüşümü, T.C. Başbakanlık Sosyal Hizmetler ve Çocuk Esirgeme Müdürlügü Kurumu, Küreselleşen Dünyada Sosyal Hizmetlerin Konumu Hedefleri ve Geleceği Sempozyumu.

ERSÖZ, Halis Yunus (2014), Yerel Yönetimlerin Sosyal Politika Alanındaki Rolü, http://www.sosyalpolitikalar.org/makaleler/sosyal-beledyeclk/145-yerel-yoenetmlernsosyal-poltkaalanindak-rolue, 11.10.2014.

ERYILMAZ, Bilal (2013), Kamu Yönetimi, Kocaeli: Umuttepe Yayınları.

ES, Muharrem (2007), Kent Üzerine Düşünceler, İstanbul: Plato Danışmanlık Eğitim A.Ş.

GÖYMEN, Korel (1997), Türkiye'de Kent Yönetimi, İstanbul: Boyut Matbaacılık.

GÖZE, Ayferi (1995), Liberal Marksistte Faşist ve Sosyal Devlet, İstanbul, Beta Basım Yayım Dağıtım.

http://www.konya.bel.tr/sayfadetay.php?sayfaID=151 23.11.2014.

http://www.mevzuat.gov.tr/Metin.Aspx?MevzuatKod=1.5.2709\&sourceXmlSearch=\&MevzuatIlisk $\mathrm{i}=0$ 23.12.2014.

http://www.mevzuat.gov.tr/Metin.Aspx?MevzuatKod=1.5.5216\&Mevzuatlliski=0\&sourceXmlSear $\mathrm{ch}=(18.10 .2014)$

http://www.mevzuat.gov.tr/Metin.Aspx?MevzuatKod=1.5.5302\&sourceXmlSearch=\&MevzuatIlisk $\mathrm{i}=0 \quad 10.11 .2014$.

http://www.mevzuat.gov.tr/MevzuatMetin/1.5.5393.pdf 18.11.2014.

http://www.mevzuat.gov.tr/Metin1.Aspx?MevzuatKod=1.5.5393\&MevzuatIliski=0\&sourceXm1Sea $\mathrm{rch}=\&$ Tur= $=1 \&$ Tertip $=5 \& \mathrm{No}=5393 \quad 10.10 .2014$.

http://www.tbmm.gov.tr/kanunlar/k5216.html 24.11.2014.

KELEŞ, Sümeyra, (2008), Türkiye'de Sosyal Belediyecilik Uygulamaları ve Ankara Büyükşehir Belediyesi Örneği, Yüksek Lisans Tezi, Afyon Kocatepe Üniversitesi Sosyal Bilimler Enstitüsü.

KORAY, Meryem ve Alper Topçuoğlu (1995), Sosyal Politika, Bursa: Ezgi Kitabevi.

KURT, Mustafa ve Özlem Yaşar Uğurlu (2007), "Yeni Kamu Yönetimi ve Yeni Kamu Yönetimi Yaklaşımının Gelişiminde Avrupa Birliği'nin Rolü: İlerleme Raporları İçerik Analizi”, Afyon Kocatepe Üniversitesi, İktisadi ve İdari Bilimler Fakültesi Dergisi, C: 9, S: 2, 81109.

ÖKMEN, Mustafa ve Bekir Parlak (2008), Kuramdan Uygulamaya Yerel Yönetimler İlkeler, Yaklaşımlar ve Mevzuat, Bursa: Alfa Aktüel.

ÖZDEMİR, Süleyman (2006), "Refah Devleti: Altın Çağ’dan Belirsiz Geleceğe”, Sosyal Politikalar Dergisi, S: 1, ss. 26-30.

ÖZDEN, Kemal ve Melek Zorlu (2010), Yerel Yönetimlerde Aç1lım: 1580 Sayılı Belediye Kanunu ile 5393 Sayılı Belediye Kanunu Arasındaki Farklar, http://www.yerelsiyaset.com/v4/sayfalar.php?goster=ayrinti\&id=1102. 01.12.2014.

ÖZER, M. Akif (2005), Günümüzün Yükselen Değeri: Yeni Kamu Yönetimi, Sayıştay Dergisi, S: 59, 3- 46.

PEKTAŞ, Ethem Kadri (2010), “Türkiye'de Sosyal Belediyecilik Uygulamaları ve Temel Sorunlar", Sakarya Üniversitesi Sosyal Bilimler Enstitüsü Akademik İncelemeler Dergisi, C:5, S: 1, 5- 22.

SELEK Öz, Cihan ve Yıldırımalp, Sinem (2009), Türkiye'de Kentsel Yoksullukla Mücadelede Sosyal Belediyeciliğin Rolü, Uluslararası Sosyal Haklar Sempozyumu, 22-23 Ekim 2009 Akdeniz Üniversitesi, 453-463. 
SERTAÇ, Güleç (2008), “1945-1980 Yılları arasında Türkiye'de Refah Devleti”, Yerel Siyaset, Temmuz, 48-55.

ŞENKAL, Abdülkadir (2011), Küreselleşme Sürecinde Sosyal Politika, İstanbul, Alfa Yayınları.

T.C. İçişleri Bakanlı̆̆g, Bilgi İşlem Dairesi Başkanlığı (2007), Coğrafi Tabanlı İl-Kent Yönetim Ve Bilgi Sistemi Teknik Kilavuzu, Ankara.

T.C. İçişleri Bakanlığı, Mahalli İdareler Genel Müdürlüğü (2012), 2011 Yılı Mahalli İdareler Genel Faaliyet Raporu, Ankara.

TALAS, Cahit (1992), Türkiye'nin Açıklamalı Sosyal Politika Tarihi, Ankara: Bilgi Yayınevi.

TEKELİ, İlhan (1992), Belediyecilik Yazıları (1976-1991), İstanbul, IULA-EMME Uluslar arası Yerel Yönetimler Birliği Doğu Akdeniz ve Ortadoğu Bölge Teşkilatı Yayınları, Kent Basımevi.

TOKSÖZ, Fikret, Ali Ercan Özgür, Öykü Uluçay, Levent Koç, Gülay Atar, Nilüfer Akalın (2009), Yerel Yönetim Sistemleri Türkiye Fransa İspanya İtalya Polonya Çek Cumhuriyeti, İstanbul: TESEV Yayınları.

TOPRAK, Zerrin (2006), Yerel Yönetimler, Ankara: Nobel Yayın Dağıtım. 